J. Akademika Kim. 5(4): 153-158, November 2016

ISSN 2302-6030 (p), 2477-5185 (e)

\title{
UJI EFEKTIVITAS EKSTRAK TANAMAN PUTRI MALU (Mimosa pudica Linn) SEBAGAI BAHAN PENGAWET ALAMI TOMAT
}

\section{Effectivity Test of Shameful Plant/Putri Malu (Mimosa pudica Linn) Extract as Natural Preservative for Tomatoes}

\author{
*Fadlian, Baharuddin Hamzah, P. Hengky Abram \\ Pendidikan Kimia/FKIP - University of Tadulako, Palu - Indonesia 94118 \\ Received 01 September 2016, Revised 03 October 2016, Accepted 01 November 2016
}

\begin{abstract}
Putri malu plant (Mimosa pudica Linn) is known to contain saponin which is antibacterial compounds that can be used as a preservative. This study aims to prove whether the putri malu extracts can be used as a natural preservative for tomato and to determine the concentration of putri malu extracts to preserve tomatoes. The extraction method used was maceration and iodimetric titration to determine the levels of vitamin $C$ before and after preservation. The results showed that the putri malu extract can be used as a natural preservative for tomatoes and the most effective concetration in preserving tomatoes is of 6\%, ie for 11 days. At this level of concentration vitamin C showed the smallest value among others concentration. Where it decreasing from $36.373 \mathrm{mg} / 100 \mathrm{~g}$ into $34.613 \mathrm{mg} / 100 \mathrm{~g}$ of material.
\end{abstract}

Keywords: putri malu (mimosa pudica linn), a natural preservative, tomato, levels of vitamin C.

\section{Pendahuluan}

Tomat merupakan tanaman sayuran buah yang sangat dibutuhkan oleh manusia untuk memenuhi kebutuhan hidupnya. Hal ini disebabkan karena kandungan gizi buah tomat yang terdiri dari vitamin dan mineral sangat berguna untuk mempertahankan kesehatan dan mencegah penyakit (Surtinah, 2007). Salah satu jenis sayuran yang sangat dikenal dan digemari oleh sebagian besar lapisan masyarakat ini memiliki rasa yang manis-manis asam serta dapat memberikan kesegaran pada tubuh. Banyak sekali penggunaan buah tomat, antara lain sebagai bumbu sayur, lalap, makanan yang diawetkan (saus tomat), buah segar, atau minuman (juice) (Tim Penulis PS, 2004).

Produksi buah tomat pada tahun 2013 mencapai 100.799 ton atau sekitar 16,7 \% dari total produksi sayuran (Dinas Pertanian Provinsi Sulawesi Tengah, 2013). Namun, kekurangannya adalah tomat termasuk komoditi hortikultura yang sangat mudah rusak, baik yang disebabkan oleh kerusakan mekanis dan fisiologi lanjut maupun kerusakan yang

\section{*Correspondence:}

Fadlian

Program Studi Pendidikan Kimia, Fakultas Keguruan dan

Ilmu Pendidikan, Universitas Tadulako

email: fadlianfade@gmail.com

Published by Universitas Tadulako 2016 disebabkan oleh mikrobiologi (pembusukan).

Daya tahan buah tomat dapat ditingkatkan melalui pemberian pengawet. Terdapat dua jenis pengawet yaitu pengawet sintesis dan pengawet alami (Adawiyah, dkk., 1998). Saat ini penggunaan bahan pengawet sintetis tidak direkomendasikan oleh Badan Pengawas Obat dan Makanan (BPOM) karena diduga dapat menimbulkan penyakit kanker (carcinogen agent). Karena itu perlu dicari alternatif lain yaitu bahan pengawet alami yang bersumber dari bahan alam (Barus, 2009).

Bahan pengawet alami terdapat pada hampir semua tumbuh-tumbuhan dan buahbuahan yang tersebar di seluruh tanah air terutama yang mengandung saponin. Saponin dapat bekerja sebagai antibakteri dan salah satu tanaman yang mengandung senyawa kimia saponin adalah putri malu (Tamilarasi \& Ananthi, 2012). Senyawa saponin termasuk senyawa polifenol, yang mana senyawa ini dapat menghambat bakteri dengan cara merusak membran sitoplasma pada bakteri. Kerusakan pada membran sitoplasma dapat mencegah masuknya bahan-bahan makanan atau nutrisi yang diperlukan bakteri untuk menghasilkan energi akibatnya bakteri akan mengalami hambatan pertumbuhan dan bahkan kematian 
(Jaya, 2010).

Putri malu merupakan salah satu tumbuhan yang berpotensi sebagai antimikroba patogen pangan (Parhusip, dkk., 2010). Penelitian lainnya yaitu yang dilakukan oleh Abirami, dkk. (2014) juga menunjukkan bahwa ekstrak tumbuhan putri malu memiliki kemampuan penghambatan terhadap aktivitas bakteri dan jamur patogen. Hal ini didukung dengan uji fitokimia yang menunjukkan adanya senyawa saponin yang memiliki potensi untuk menghambat mikroba (Ranjan, 2013).

Potensi dari tanaman putri malu tersebut masih kurang dimanfaatkan di Indonesia. Hal ini dapat dilihat dari keberadaanya di lingkungan sebagai tanaman pengganggu. Pemanfaatannya sebagai antibakteri untuk mengawetkan buah tomat diharapkan dapat mengatasi masalah tersebut. Berdasarkan uraian di atas maka peneliti tertarik untuk mengetahui efektivitas ekstrak tanaman putri malu (Mimosa pudica) sebagai pengawet alami tomat.

\section{Metode \\ Alat dan Bahan}

Peralatan yang digunakan pada penelitian ini adalah oven, blender, baskom, tabung reaksi, neraca digital, erlenmeyer $1000 \mathrm{~mL}$, shaker, gelas ukur $250 \mathrm{~mL}$ dan $10 \mathrm{~mL}$, labu ukur 100 $\mathrm{mL}$, pipet tetes, corong, kertas saring, vacuum pump, rotary evaporator, botol kecil, keranjang kecil, spatula, batang pengaduk, buret $25 \mathrm{~mL}$, klem dan statif, serta gelas kimia $100 \mathrm{~mL}$ dan $1000 \mathrm{~mL}$. Sedangkan bahan yang digunakan adalah tanaman putri malu, buah tomat, etanol (Merck), larutan $\mathrm{HCl} 2 \mathrm{~N}$, larutan amilum $1 \%$, larutan standar iodine $0,01 \mathrm{~N}$, aquades dan alumunium foil.

\section{Cara Kerja}

Tanaman putri malu yang digunakan dipisahkan dari kotoran lalu dicuci bersih. Kemudian dikeringkan-anginkan selama 30 hari. Selanjutnya bahan dihaluskan menggunakan blender dan diayak hingga diperoleh serbuk halus dari tanaman putri malu. Selanjutnya melakukan uji pendahuluan (uji busa saponin) dengan cara memasukkan 0,5 gram simplisia ke dalam tabung reaksi yang telah berisikan $10 \mathrm{~mL}$ aquades, mengocoknya dan menambahkan 1 tetes larutan $\mathrm{HCl} 2 \mathrm{~N}$. Kemudian proses ekstrasi serbuk tanaman putri malu sebanyak 200 gram selama $3 \times 24$ jam dengan menggunakan $600 \mathrm{~mL}$ pelarut etanol. Kemudian, mengentalkan ekstrak dengan menggunakan rotary evaporator pada suhu $50^{\circ} \mathrm{C}$ dengan kecepatan $8 \mathrm{rpm}$. Selanjutnya, memasukkan ekstrak kental tersebut ke dalam oven pada suhu $30^{\circ} \mathrm{C}$ sampai $40^{\circ} \mathrm{C}$. Setelah itu, membuat larutan ekstrak dengan konsentrasi $0 \%, 2 \%, 4 \%, 6 \%$ dan $8 \%$.

Pengawetan buah tomat dilakukan dengan cara mencelup buah tomat ke dalam larutan ekstrak selama 5 detik dan melakukan pengamatan selama beberapa hari. Parameter yang diamati adalah perubahan tekstur, warna dan kadar vitamin $C$ sebelum dan sesudah pengawetan. Penentuan kadar vitamin C dilakukan dengan cara menimbang 100 gram buah tomat dan menghaluskannya dengan menggunakan blender. Selanjutnya, mengambil 20 gram sluri dan mengencerkannya hingga 100 $\mathrm{mL}$. Kemudian, menyaring larutan sluri hingga diperoleh filtrat buah tomat. Selanjutnya, memasukkan $25 \mathrm{~mL}$ filtrat, $20 \mathrm{~mL}$ aquades dan $2 \mathrm{~mL}$ amilum $1 \%$ ke dalam erlenmeyer. Setelah itu, melakukan titrasi dengan menggunakan larutan standar iodine $0,01 \mathrm{~N}$ sebagai titrannya.

\section{Hasil dan Pembahasan}

Penelitian ini dilakukan untuk membuktikan bahwa ekstrak tanaman putri malu efektif digunakan sebagai pengawet alami tomat dan menentukan konsentrasi efektif dari ekstrak tanaman putri malu yang dapat mengawetkan buah tomat lebih lama. Metode yang digunakan dalam penelitian ini adalah maserasi untuk pembuatan ekstrak dan titrasi iodometri untuk menentukan kadar vitamin C sebelum dan sesudah pengawetan.I

\section{Uji Pendahuluan (Uji Busa Saponin)}

Penelitian yang dilakukan oleh Jaya (2010) menyebutkan bahwa akar putri malu memiliki aktivitas antibakteri. Senyawa aktif akar putri malu yang berkhasiat sebagai anti bakteri adalah saponin. Untuk membuktikan adanya senyawa aktif tersebut di dalam sampel tanaman putri malu yang kemudian dapat dimanfaatkan sebagai pengawet alami buah tomat, maka dilakukan uji pendahuluan saponin berupa uji busa. Tinggi busa yang stabil setelah ditetesi $\mathrm{HCl} 2 \mathrm{~N}$ membuktikan bahwa serbuk tanaman putri malu mengandung senyawa saponin. Busa yang timbul disebabkan karena senyawa saponin mengandung senyawa yang sebagian larut dalam air (hidrofilik) dan senyawa yang larut dalam pelarut nonpolar (hidrofobik) sebagai surfaktan yang dapat menurunkan tegangan permukaan. 


\section{Ekstrak Tanaman Putri Malu yang Diperoleh}

Hasil ekstraksi tanaman putri malu (Mimosa pudica Linn) dari 200 gram sampel menghasilkan 20,1 gram ekstrak kering. Ekstrak tersebut dibuat menjadi 5 jenis konsenrasi yakni $0 \%, 2 \%, 4 \%, 6 \%$ dan $8 \%$. Buah tomat yang diawetkan untuk setiap konsentrasi ekstrak tanaman putri malu adalah 14 buah. Proses pengawetan buah tomat menggunakan ekstrak tanaman putri malu memperoleh hasil yang berbeda-beda.

\section{Daya Tahan Buah Tomat}

Setelah dilakukan proses pengawetan pada tomat, maka diperoleh pengamatan terhadap daya tahan tomat yaitu seperti pada Tabel 1 . Pengamatan dihentikan ketika banyak terdapat buah tomat yang mengalami perubahan tekstur dan perubahan warna.

Tabel 1. Hasil Pengamatan Daya Tahan Buah Tomat

\begin{tabular}{cc}
\hline $\begin{array}{c}\text { Konsentrasi Ekstrak } \\
\text { Tanaman Putri Malu (\%) }\end{array}$ & $\begin{array}{c}\text { Daya Tahan } \\
\text { Tomat (hari) }\end{array}$ \\
\hline 0 & 6 \\
2 & 8 \\
4 & 9 \\
6 & 11 \\
8 & 11 \\
\hline
\end{tabular}

Daya tahan tomat yang diawetkan menggunakan ekstrak tanaman putri malu ternyata berbeda-beda untuk tiap konsentrasi. Normalnya buah tomat segar dapat bertahan hingga 5 hari. Data pada Tabel 1. menunjukkan daya tahan tomat yang diawetkan menggunakan $0 \%$ ekstrak tanaman putri malu atau sebagai kontrol memiliki daya tahan selama 6 hari. Untuk pengawetan menggunakan konsentrasi $2 \%$ ekstrak memiliki daya tahan sampai 8 hari. Pada konsentrasi 4\% dan 6 ekstrak memiliki daya tahan masa simpan selama 9 hari. Sedangkan untuk konsentrasi 6\% dan $8 \%$ ekstrak memiliki daya simpan yang sama yaitu mampu membuat tomat bertahan hingga 11 hari. Hal ini menunjukkan bahwa ekstrak tanaman putri malu mampu menghambat laju pembusukan pada tomat yang disebabkan oleh bakteri. Hanya saja ada beberapa faktor pembusukan lain pada buah tomat yang tidak dapat dicegah oleh pengawet ini.

\section{Pengamatan Mutu Tomat}

Pengamatan dihentikan ketika buah tomat telah menunjukan tanda-tanda kerusakan melalui perubahan tekstur dan warna yaitu sebagian besar buah tomat telah bertekstur lembek dan berwarna merah tua mendekati coklat. Buah tomat mengalami perubahan warna dari merah muda - merah $(\mathrm{MM}-\mathrm{M})$ kemudian merah (M) dan merah tua (MT).

Tabel 2. Pengamatan Tekstur Buah Tomat

\begin{tabular}{|c|c|c|c|c|c|c|c|c|c|c|c|}
\hline \multirow{3}{*}{ Konsentrasi } & \multicolumn{11}{|c|}{ Hari ke- } \\
\hline & 1 & 2 & 3 & 4 & 5 & 6 & 7 & 8 & 9 & 10 & 11 \\
\hline & \multicolumn{11}{|c|}{ Jumlah buah tomat yang lembek } \\
\hline $0 \%$ & $\begin{array}{c}\text { Semua } \\
\text { tomat } \\
\text { tekstumya } \\
\text { keras }\end{array}$ & 2 & 4 & 5 & 7 & 11 & - & - & - & - & - \\
\hline $2 \%$ & $\begin{array}{c}\text { Semua } \\
\text { tomat } \\
\text { tekstumya } \\
\text { keras }\end{array}$ & 1 & 1 & 3 & 3 & 6 & 10 & 11 & - & - & - \\
\hline $4 \%$ & $\begin{array}{c}\text { Semua } \\
\text { tomat } \\
\text { tekstumya } \\
\text { keras }\end{array}$ & $\begin{array}{c}\text { Semua } \\
\text { tomat } \\
\text { tekstumya } \\
\text { keras }\end{array}$ & 2 & 2 & 3 & 4 & 8 & 10 & 11 & - & - \\
\hline $6 \%$ & $\begin{array}{c}\text { Semua } \\
\text { tomat } \\
\text { tekstrumya } \\
\text { keras }\end{array}$ & $\begin{array}{c}\text { Semua } \\
\text { tomat } \\
\text { tekstumya } \\
\text { keras }\end{array}$ & 1 & 1 & 2 & 3 & 3 & 6 & 9 & 10 & - \\
\hline $8 \%$ & $\begin{array}{c}\text { Semua } \\
\text { tomat } \\
\text { tekstumya } \\
\text { keras }\end{array}$ & $\begin{array}{c}\text { Semua } \\
\text { tomat } \\
\text { tekstumya } \\
\text { keras }\end{array}$ & 1 & 1 & 1 & 2 & 3 & 6 & 8 & 10 & 11 \\
\hline
\end{tabular}

Tabel 3. Pengamatan Perubahan Warna Buah Tomat Selama Pengawetan

\begin{tabular}{|c|c|c|c|c|c|c|c|c|c|c|c|}
\hline \multirow{3}{*}{$\begin{array}{c}\text { Konsen- } \\
\text { trasi }\end{array}$} & \multicolumn{11}{|c|}{ Hari ke- } \\
\hline & 1 & 2 & 3 & 4 & 5 & 6 & 7 & 8 & 9 & 10 & 11 \\
\hline & \multicolumn{11}{|c|}{ Perubahan wama buah tomat } \\
\hline $0 \%$ & $\begin{array}{c}\mathrm{MM} \\
-\mathrm{M}\end{array}$ & M & M & M & MT & MT & - & - & - & - & - \\
\hline $2 \%$ & $\begin{array}{c}\mathrm{MM} \\
-\mathrm{M}\end{array}$ & $\begin{array}{c}\mathrm{MM} \\
-\mathrm{M}\end{array}$ & M & M & M & M & MT & MT & - & - & - \\
\hline $4 \%$ & $\begin{array}{c}\mathrm{MM} \\
-\mathrm{M}\end{array}$ & $\begin{array}{c}\mathrm{MM} \\
-\mathrm{M}\end{array}$ & $\begin{array}{c}\mathrm{MM} \\
-\mathrm{M}\end{array}$ & M & M & M & M & MT & MT & - & - \\
\hline $6 \%$ & $\begin{array}{c}\mathrm{MM} \\
-\mathrm{M}\end{array}$ & $\begin{array}{c}\mathrm{MM} \\
-\mathrm{M}\end{array}$ & $\begin{array}{c}\mathrm{MM} \\
-\mathrm{M}\end{array}$ & $\begin{array}{c}\mathrm{MM} \\
-\mathrm{M}\end{array}$ & M & M & M & M & M & MT & MT \\
\hline $8 \%$ & $\begin{array}{c}\mathrm{MM} \\
-\mathrm{M}\end{array}$ & $\begin{array}{c}\mathrm{MM} \\
-\mathrm{M}\end{array}$ & $\begin{array}{c}\mathrm{MM} \\
-\mathrm{M}\end{array}$ & $\begin{array}{c}\mathrm{MM} \\
-\mathrm{M}\end{array}$ & M & M & M & M & M & MT & MT \\
\hline
\end{tabular}

Kelunakan buah tomat meningkat seiring dengan lama penyimpanan dan tingkat kematangan. Munculnya keriput pada kulit tomat diduga karena terjadinya proses transpirasi yang menyebabkan kehilangan air tinggi (Suhardjo, 1992). Kehilangan air yang cukup tinggi menyebabkan terjadinya pengkerutan sel buah dan berdampak pada pengkerutan kulit buah, sehingga akan mempengaruhi penampakan buah. Kehilangan air pada produk segar juga dapat menurunkan 
mutu dan menimbulkan kerusakan. Transpirasi pada buah menyebabkan ikatan sel menjadi longgar dan ruang udara menjadi besar seperti mengeriput, keadaan sel yang demikian menyebabkan perubahan volume ruang udara, tekanan turgor, dan kekerasan buah (Novita, dkk., 2012). Berdasarkan data pada Tabel 2 Perubahan tekstur pada buah tomat tersebut dapat dibuat ke dalam bentuk grafik sebagai berikut.

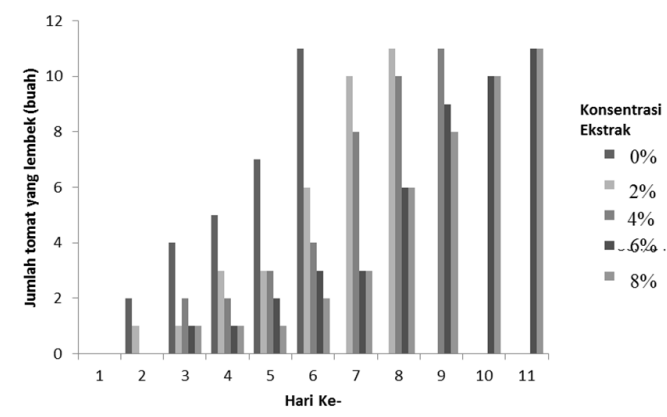

Gambar 1. Grafik Perubahan Tekstur Buah Tomat Selama Masa Pengawetan

Gambar 1 menunjukkan bahwa pada hari pertama pengawetan, buah tomat belum mengalami perubahan tekstur sama sekali. Namun, pada hari ke-2 barulah buah tomat mengalami perubahan tekstur. Kemudian diikuti oleh konsentrasi-konsentrasi lain pada hari selanjutnya. Buat tomat pada konsentrasi $0 \%$ lebih cepat mengalami perubahan tekstur dibandingkan tomat pada konsentrasi lainnya. Hal ini menunjukkan bahwa semakin besar konsentrasi yang digunakan semakin besar kemampuan untuk mengawetkan. Selain perubahan tekstur menjadi lembek yang disebabkan oleh mikroba, ada beberapa faktor lain yang juga dapat mempercepat terjadinya perubahan pada tekstur tomat yakni transpirasi. Laju transpirasi dipengaruhi oleh faktor internal (morfologis/anatomis, rasio permukaan terhadap volume, kerusakan fisik, umur panen) dan faktor eksternal (suhu, RH, pergerakan udara dan tekanan atmosfir). Transpirasi yang berlebihan akan menyebabkan produk mengalami pengurangan berat, penurunan daya tarik (karena layu), nilai tekstur dan nilai gizi. Pengendalian laju transpirasi dilakukan dengan pelapisan, penyimpanan dingin, atau memodifikasi atmosfir (Koswara, 2009). Sedangkan ekstrak tanaman putri malu yang telah diencerkan pada berbagai variasi konsentrasi memiliki kekentalan yang rendah. Ekstrak tersebut kurang efektif digunakan untuk melapisi permukaan buah tomat. Ekstrak tanaman putri malu dapat mempertahankan kesegaran buah tomat hanya dengan menghambat kerusakan fisioligis yang disebabkan oleh bakteri. Oleh karena itu, konsentrasi 6\% dan 8\% pada hari ke-11 mengalami perubahan tekstur yang sama. Walaupun pada hari-hari sebelumnya memiliki perubahan tekstur yang berbeda. Dimana pada hari tersebut jumlah buah tomat yang bertekstur lembek adalah sama yakni 11 buah.

Buah tomat yang masih muda mengandung lycopersicin dan ketika buahnya semakin matang, lycopersicin lama-kelamaan akan hilang sendiri. Seiring dengan proses pematangan, warna hijau dari tomat akan berubah menjadi kuning. Ketika buahnya telah matang, warnanya akan menjadi merah (Tim Penulis PS, 2004). Warna merah pada tomat disebabkan karena adanya likopen. Selama penyimpanan likopen mengalami perubahan yaitu proses oksidasi. Faktor terpenting yang memperbesar penurunan likopen selama pe $\neg$ nyimpanan adalah adanya oksigen yang menyebabkan ter-jadinya oksidasi (Shi \& Maguer, 2002). Buah tomat berubah dari warna merah mudamerah menjadi merah kemudian merah tua seiring lama waktu pengawetan. Hal tersebut terlihat pada Tabel 3, dimana sebagian besar buah tomat telah menunjukkan tanda-tanda kerusakan yakni mengalami perubahan warna menjadi merah-tua. Penyebab kerusakan pada buah tomat adalah bakteri $E$. carotovora. Gejala awal yang terlihat yaitu terbentuk luka basah kecil, yang semakin membesar baik diameter maupun kedalamannya. Daerah yang terinfeksi menjadi lembek sementara warna permukaannya memudar. Jaringan pada daerah yang terinfeksi menjadi berwarna krem dan tipis, kemudian menjadi hancur. Permukaan luar akan terlihat utuh namun dibagian dalamnya berubah menjadi lembek, berair, dan berwarna coklat (Agrios, 1997). Oleh karena itu pengamatan dihentikan ketika buah tomat telah lembek serta berubah warna menjadi merah tua atau mendekati warna coklat yang menunjukkan bahwa likopen telah berkurang.

\section{Kadar Vitamin C}

Analisis kadar vitamin $\mathrm{C}$ buah tomat dilakukan sebelum dan sesudah pengawetan dengan melihat perubahan tekstur yang lembek serta perubahan warna menjadi merah tua. Titrasi dilakukan menggunakan metode 
iodimetri dengan 3 kali pengulangan, diperoleh data seperti yang tertera pada Tabel 4 .

Tabel 4. Hasil Analisis Kadar Vitamin C (per $100 \mathrm{~g}$ bahan) pada Buah Tomat

\begin{tabular}{ccc}
\hline $\begin{array}{c}\text { Kadar Vitamin C } \\
(\mathrm{mg}) \text { Sebelum } \\
\text { Pengawetan }\end{array}$ & $\begin{array}{c}\text { Konsentrasi } \\
\text { Ekstrak } \\
(\%)\end{array}$ & $\begin{array}{c}\text { Kadar Vitamin C } \\
(\mathrm{mg}) \text { sesudah } \\
\text { pengawetan }\end{array}$ \\
\hline 36,373 & 0 & 17,013 \\
36,373 & 2 & 23,460 \\
36,373 & 4 & 26,987 \\
36,373 & 6 & 34,613 \\
36,373 & 8 & 30,506 \\
\hline
\end{tabular}

Komposisi buah tomat yang cukup besar adalah vitamin C. Kandungan asam askorbat tertinggi pada buah tomat ialah selama proses pembentukan atau pertumbuhannya di pohon dan akan menurun selama pematangan atau penyimpanan (Muchtadi, dkk., 1993). Hal tersebut terlihat pada Gambar 2 hasil penentuan kadar vitamin $C$ pada tiap konsentrasi setelah proses pengawetan menggunakan metode titrasi iodimetri berdasarkan Tabel 4

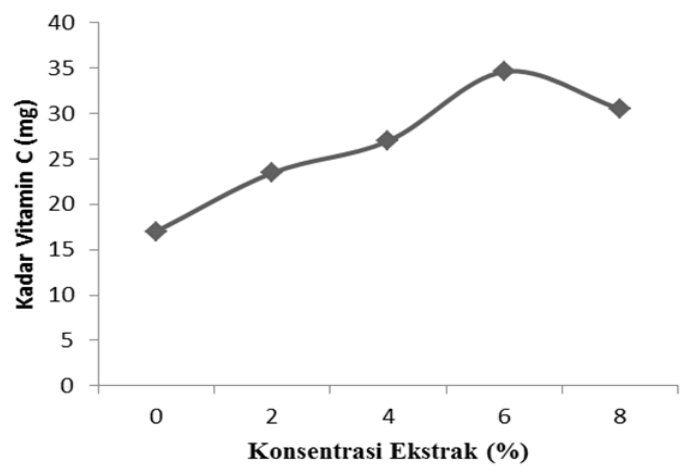

Gambar 2. Hubungan Antara Kadar Vitamin C (mg) dan Konsentrasi Ekstrak (\%)

Kadar vitamin C buah tomat sebelum diawetkan yaitu sebesar $36,373 \mathrm{mg} / 100 \mathrm{~g}$ bahan. Sedangkan kadar vitamin $\mathrm{C}$ buah tomat segar yaitu sebesar $40 \mathrm{mg} / 100 \mathrm{~g}$ bahan (Tim Penulis PS, 2004). Setelah melihat tanda-tanda kerusakan pada buah tomat yaitu bertekstur lembek dan warna yang berubah menjadi merah tua atau mendekati coklat, maka pengamatan dihentikan. Kemudian buah tomat tersebut dititrasi untuk mengetahui kadar vitamin C yang tersisa.

Kadar vitamin $\mathrm{C}$ buah tomat pada tiap konsentrasi setelah diawetkan mengalami penurunan. Namun, pada tiap-tiap konsentrasi memiliki penurunan kadar vitamin $\mathrm{C}$ yang berbeda-beda. Dimana semakin besar konsentrasi pengawet maka semakin sedikit kadar vitamin C yang berkurang selama penyimpanan. Grafik pada gambar 2 menunjukkan bahwa buah tomat pada konsentrasi $0 \%$ memiliki kadar vitamin C paling sedikit yaitu $17,013 \mathrm{mg} / 100 \mathrm{~g}$ bahan. Sedangkan kadar vitamin $C$ paling besar adalah buah tomat yang diberi pengawet pada konsentrasi 6\% yakni sebesar 34,613 mg/100 $\mathrm{g}$ bahan. Hal ini menunjukkan bahwa ekstrak tanaman putri malu dapat digunakan sebagai pengawet alami tomat. Namun, buah tomat setelah dipanen masih melakukan proses metabolisme menggunakan cadangan makanan yang terdapat dalam buah. Berkurangnya cadangan makanan tersebut tidak dapat digantikan karena buah sudah terpisah dari pohonnya, sehingga mempercepat proses hilangnya nilai gizi buah dan mempercepat proses pemasakan (Novita, dkk., 2012). Oleh karena itu, buah tomat pada konsentrasi $8 \%$ dengan lama penyimpanan yang sama yaitu 11 hari mengalami penurunan kadar vitamin C lebih besar dibanding buah tomat pada konsentrasi 6\%. Adapun kadar vitamin $\mathrm{C}$ buah tomat pada konsentrasi $8 \%$ setelah pengawetan yaitu $30,506 \mathrm{mg} / 100 \mathrm{~g}$ bahan.

\section{Kesimpulan}

Ekstrak tanaman putri malu dapat digunakan sebagai pengawet alami pada buah tomat. Hal tersebut terlihat dari perubahan tekstur dan warna buah tomat yang diawetkan dapat bertahan lebih lama dibandingkan tomat tanpa pengawet. Ekstrak tanaman putri malu yang efektif dalam mengawetkan buah tomat adalah pada konsentrasi 6\% dengan lama penyimpanan selama 11 hari. Dimana pada konsentrasi ini terjadi penurunan kadar vitamin $\mathrm{C}$ paling sedikit dibanding konsentrasi lainnya yaitu $34,613 \mathrm{mg} / 100 \mathrm{~g}$ dari kadar awal sebesar $36,373 \mathrm{mg} / 100 \mathrm{~g}$ bahan.

\section{Ucapan Terima Kasih}

Penulis mengucapkan terima kasih kepada kepala laboran laboratorium Agroteknologi FAPERTA dan semua pihak yang telah membantu dalam pelaksanaan penelitian ini.

\section{Referensi}

Abirami, S. K. G., Mani, K. S., Devi, M. N., 
\& Devi, P. N. (2014). The antimicrobial activity of mimosa pudica l. International Journal of Ayurveda and Pharma Research, 2(1), 105-108.

Adawiyah, R., Soekarto, \& Jenie, B. (1998). Ekstraksi komponen antimikrobia dari biji buah atung. Prosiding Seminar Nasional Teknologi Pangan dan Gizi.

Agrios, G. N. (1997). Plant pathology (4rd ed.). New York: Academic Press.

Barus, P. (2009). Pemanfaatan bahan pengawet dan antiokidan alami pada industri bahan makanan. Pidato Pengukuhan Jabatan Guru Besar Tetap dalam Bidang Ilmu Kimia Analitik pada Fakultas Matematika dan Ilmu Pengetahuan Alam, diucapkan dihadapan Rapat Terbuka Universitas Sumatera Utara. Medan.

Dinas Pertanian Provinsi Sulawesi Tengah. (2013). Data sayuran dan buab-buahan semusim tahun 2013. Palu: Dinas Pertanian.

Jaya, A. M. (2010). Isolasi dan uji efektivitas antibakteri senyawa saponin dari akar putri malu (mimosa pudica). Skripsi, Jurusan Kimia Universitas Islam Negeri (UIN) Maulana Malik Ibrahim, Malang.

Koswara, S. (2009). Pengawet alami untuk produk dan bahan pangan. Produksi: eBookPangan.com. Retrieved 26 November 2014, from http://tekpan.unimus.ac.id/ wp-content/uploads/2013/07/pengawetalami-untuk-produk-dan-bahan-pangan . pdf

Muchtadi, D., Palupi, N. S., \& Astawan, M. (1993). Metabolisme zat gizi. Jakarta: Pustaka Sinar Harapan.
Novita, M., Satriana, Martunis, Rohaya, S., \& Hasmarita, E. (2012). Pengaruh pelapisan kitosan terhadap sifat fisik dan kimia tomat segar (lycopersicum pyriforme) pada berbagai tingkat kematangan. Jurnal Teknologi dan Industri Pertanian Indonesia 4(3), 1-8.

Parhusip, A. J. N., Friska, E., \& Saputra, R. D. (2010). Potensi aktivitas antimikroba ekstrak putri malu (mimosa pudica 1.) terhadap mikroba patogen pangan. Jurnal Ilmu dan Teknologi Pangan, 8(1), 45-54.

Ranjan, R. K., Sathish, K., Seethalakshmi \& Rao M. R. K. (2013). Phytochemical analysis of leaves and roots of mimosa pudica collected from kalingavaram, tamil nadu. Journal of Chemical and Pharmaceutical Research, 5(5), 53-55.

Shi, J. G. M., \& Maguer. (2002). Fungtional foods biochemical and processing aspects. New York: CRC Press.

Suhardjo. (1992). Kajian fenomena kemasiran buah apel (malus sylvestris) kultivar rome beauty (Desertasi), Program Pascasarjana IPB

Surtinah. (2007). Kajian tentang hubungan pertumbuhan vegetatif dengan produksi tanaman tomat (lycopersicum esculentum, mill). Jurnal Ilmiah Pertanian, 4(1), 1-9.

Tamilarasi, T., \& Ananthi, T. (2012). Phytochemical analysis and anti microbial activity of mimosa pudica linn. Research Journal of Chemical Sciences, 2(2), 72-74.

Tim Penulis PS. (2004). Tomat pembudidayaan secara komersial. Jakarta: Penebar Swadaya. 